\title{
Apomictic species of Alchemilla from the High Atlas Mountains: revision of the genus Alchemilla (Rosaceae) in Morocco
}

\author{
Angel Romo*
}

\author{
Article info \\ Received: 10 Feb. 2021 \\ Revision received: 15 Jun. 2021 \\ Accepted: 30 Jun. 2021 \\ Published: 31 Dec. 2021 \\ Associate Editor \\ Elżbieta Cieślak
}

\begin{abstract}
A taxonomic revision of the Alchemilla in the High Atlas Mountains has been carried out. This genus is represented in Morocco by Alchemilla atlantica, A. gourzai, A. litardieri, A. mairei and by a new taxon A. boratynskii, sp. nov., described here from the High Atlas Mountains range. Data on their chorology, ecology and phenology, as well as an identification key, are provided. The conservation status of this newly described narrow endemic and the other four taxa, also endemics previously known from the Moroccan Atlas Mountains, is provided. Alchemilla hirtipes should be excluded from the flora of Morocco.
\end{abstract}

Key words: Africa, endemism, Mediterranean high mountain plants, megaforbs, plant conservation, taxonomy, wet pastures

\section{Introduction}

The genus Alchemilla is distributed mainly in the Holarctic, but occurs also on the mountains of East and South Africa, as well as Madagascar, South India, Sri Lanka and Java (Gehrke et al. 2008).

The genus Alchemilla is divided into 18 sections (Fröhner 1995) and the African ones include 5 sections (Rothmaler 1934, 1935, 1936). It comprises more than 1000 species (Fröhner 1995). It is well represented in the mountainous regions of Central and Southern Europe (Kurtto et al. 2007). In this latter region, the number of species diminishes as one goes further south, and the representatives of the genus are restricted to the more humid zones in the mountains, especially to those communities composed of elements with a boreal affinity.

Eighty-three taxa have been described from within the Iberian Peninsula, three quarters of which are found in the Pyrenees and the Cantabrian Mountains Cordillera (Fröhner 1998). In these mountain areas, the genus was far from being well known. The numerous new taxa described provide proof of this assertion (Romo 1991; Fröhner 1998).

This number descends sharply on reaching the mountains in the center of the Peninsula and in the southern Iberian mountains. Only a reduced number of species occur mainly in the Sierra Nevada Mountains (Kurtto et al. 2007), where it is only represented by five taxa from three different sections (Fröhner 1998).

Botanical Institute of Barcelona, Spanish National Research Council (CSIC-AB). Passeig del Migdia s/n, 08038 Barcelona, Spain ORCID: 0000-0001-8135-8570

* Corresponding author e-mail: angel.romo@gmail.com
In Morocco, where only four species were known, the genus is present in the higher parts of the High Atlas Mountains, where it is associated with meadows of a boreal nature and hygrophilous megaforb communities. All of these species are from section Alchemilla (Plocek 1982).

Alchemilla presents apomictic species that are not easy to identify. The number of species involved and the complexity of the detailed morphological differences between them explain why so few botanists are interested in this genus (Briggs \& Walters 2000). These macro- and micromorphological differences between taxa, due to apomixis, are persistent, and very few are dependent on the environmental conditions (Pihu et al. 2009).

Obligatory apomixis is shown by all members of the vulgaris group of genus Alchemilla (Briggs \& Walters 2000). All traces of sexual reproduction are now lost in the present day representatives of Alchemilla grex vulgaris (Briggs \& Walters 2000). The genus Alchemilla in its sense given by Gehrke et al. (2008), in which all the species of the Atlas Mountains and the Iberian Peninsula are nested, is considered to be apomictic; that is, agamospermous and of obligate gametophytic diplospory, in regard to endosperm formation and embryo development, which does not require the act of fertilization (Fröhner 1995).

\section{Material and methods}

During the field exploration of Morocco between the years 1985 and 2014, we had the opportunity of gaining access in 2002 to Oukaïmeden (Romo \& Boratyński 2007), one 
of the few valleys with easy access to the higher elevations. There, in the Oukaïmeden Valley located in the Great Central Atlas, a distinct Alchemilla population, growing alongside $A$. atlantica, was found. Various samples of the population were gathered and prepared in the $\mathrm{BC}$ herbarium in order to be studied.

On revising the $\mathrm{BC}$ material in the Botanical Institute of Barcelona, Maire's herbarium material in Montpellier (MPU) and Litardière's in Geneva $(G)$, the comparison of material and a critical study of the original description of the protologues led us to the conclusion that we were dealing with a hitherto undescribed taxon.

At the same time, and faced with the excessive brevity of the original descriptions of the Maghreb taxa, the convenience of drawing up a complete revision of all herbarium material available became evident. Revision following the lines of modern floras (Fröhner 1998), in turn, could serve to better delimit the newly-proposed species.

\section{Results}

Alchemilla boratynskii Romo, sp. nov.

(Fig. 1)

Type: Morocco. Marrakech: Oukaïmeden area, N slopes of Tizi'n-Eddi, $2700 \mathrm{~m}, 31^{\circ} 10^{\prime} \mathrm{N}, 7^{\circ} 51^{\prime} \mathrm{W}$, megaforbics, close to streams. Adam Boratyński \& Angel Romo, 26-VII-2002, Romo 10594-02 (BC - holotype); specimen 2 in BC.

Description. Perennial herb of small to medium size (6)7-8(10) cm high. Fertile stems 4-5 cm, usually shorter than the petiole length of the basal leaves, erect or ascending, with 3-4 internodes, the lower ones pilose with subadpressed hairs forming an angle of $5^{\circ}-30^{\circ}$. Basal rosette leaves with limb (2.5)3-4(4.5) cm wide, reniform $\left(260^{\circ}-\right.$ $300^{\circ}$ ) herbaceous and flat, divided to $40-43 \%$ of radius with 5-7 lobes, these slightly triangular to hyperbolic. Apex of lobes rounded, truncate, lobes of 9.5-10(11) mm width, with (4)5-6 teeth and 3(4) pairs of secondary nerves, and with the margin entire for 1-1.5(2) mm either side (10-15\% of total length); teeth of lobe distal $1 \mathrm{~mm}$ ( $5 \%$ of the limb radius, and with relation length/ width $=0.7-1.0$ ) broad-triangular, obtuse, sparsely hairy above and hairy on the margin (4-6 hairs per $\left.\mathrm{mm}^{2}\right)$, green, shiny, the lower surface with scattered hairs $\left(6-8\right.$ per $\left.\mathrm{mm}^{2}\right)$; leaf

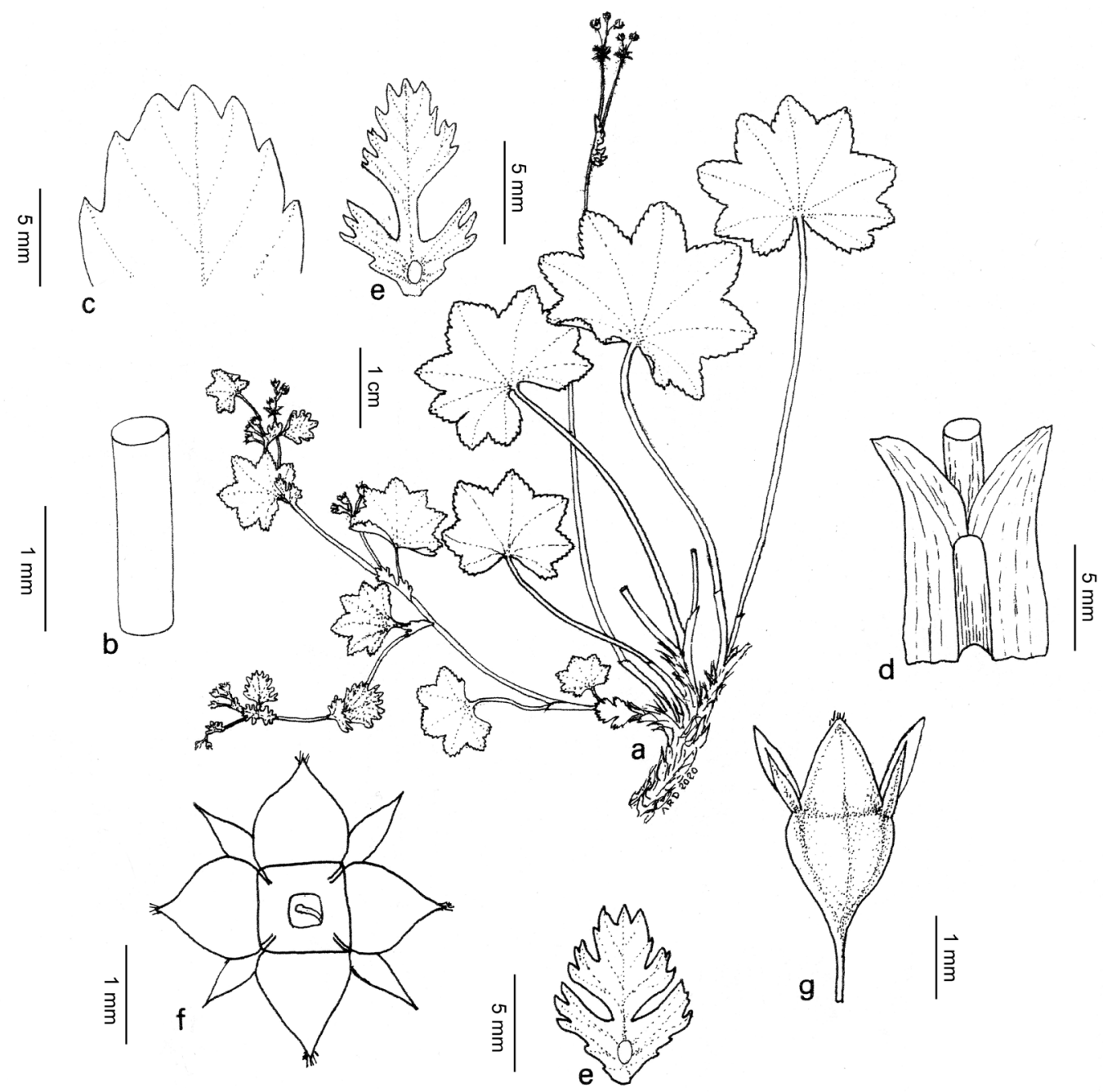

Figure 1. Alchemilla boratynskii, High Atlas, Oukaïmeden. Holotype specimen (BC, Romo 26/VII/2002); a - habit; b - stem; c - apex of the distal lobe of a rosette leaf; $\mathrm{d}$ - stipule of the rosette leaf; $\mathrm{e}$ - upper cauline leaf and stipule (laid flat); $\mathrm{f}$ - flower seen from above; $\mathrm{g}-$ side view of nucule. Drawn by A. Romo. 
petiole $0.5-0.6 \mathrm{~mm}$ thick, green and hairy, with hairs of $1-1.25 \mathrm{~mm}$, patent to slightly reflexed or ascending $\left(10^{\circ}-135^{\circ}\right)$. Stipules $\left.11-12 / 14\right) \mathrm{mm}(22-28 \%$ length of fertile stem), completely reddish brown, with auricules $3 \mathrm{~mm}$ wide, length to width 0.75 , free, with an obtuse apex, each one with 1 tooth, the ochrea incised 7-9 $\mathrm{mm}$. Cauline leaves wider, $12 \%$ of the stem length, with 3 lobes. Lower cauline leaf with stipules laterally erect and with a truncate to rounded apex, each one with 4-5(6) teeth. Upper cauline leaf, with narrow, deep lobes, each one with 3-5 teeth; stipules 4.5(2.5) mm, cut (up to 12\% of radius) into 4 teeth, these being length-width $=1.5$, homogeneous. Bracts cut to $90 \%$ of radius, lacinia of length - width $=>3$. Inflorescences with 12-18 flowers of $15 \mathrm{~cm}$ wide, narrow; partial inflorescences few-flowered, monocasios, with 5-7 flowers, dense and somewhat pseudo-umbelliform - in each monocasio there are 3-5 terminal flowers, in pseudo-umbels. Floral pedicels 1.25$2.25 \mathrm{~mm}$ (in terminal flowers $1.5-2.25 \mathrm{~mm}$ ), glabrous and divaricate. Flowers $2.5 \times 2 \mathrm{~mm}$, yellow green. Receptacle glabrous, with patent hairs in the base; at maturity a length-width ratio of 1-2.5, bell-shaped, cylindrical, finally somewhat attenuate basally, and of uniform width in the upper part. Sepals with a length-width ratio of 0.75 and $50 \%$ the length of the receptacle, arched-triangular to triangular, obtuse, hairy at the apex, erect; calyx segments of a length-width ratio of 3-4, 80-90\% the length of the receptacle, $80-90 \%$ of the sepals, and $25 \%$ the width of these, lanceolate-ovate, acute, with 3 nerves, a few hairs at the apex, finally erect to erect divaricate. Stamens with filaments $0.15-0.50 \mathrm{~mm}$; anthers $0.2 \times 0.25 \mathrm{~mm}$; approximately 0.15 , narrower than the orifice, this being $0.25-0.3 \mathrm{~mm}$, glabrous. Style purple at apex, surpassing nectary disc $0.1 \mathrm{~mm}$, stigma hemispheric to lens-shaped. Aquene $12-13 \mathrm{~mm}$, of a length-width ratio of $0.7-0.8$, rather obtuse, surpassing the disc in $50 \%$ of its length.

Etymology of new species. In honor of Prof. Dr. Adam Boratyński.

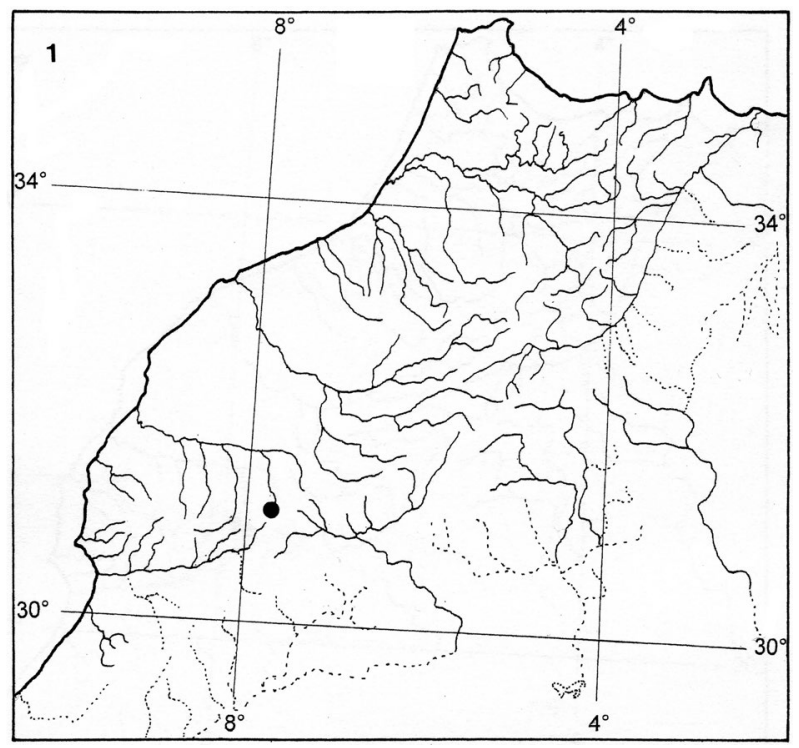

Figure 2. Distribution map of Alchemilla boratynskii.
Distribution. Endemic to the High Atlas Mountains (Fig. 2).

Habitat and phenology. In Bellis caerulescentis-Heracletum sphondyllii (Romo 2009) megaforbic plant communities close to streams, 2700-2900 m; flowering and fruiting at end of June, July and early August.

Alchemilla atlantica H. Lindb., Itin. Mediterr, Act. Soc. Sci. Fenn. N.s. B, 1: 72-73. 1932.

Type: Morocco. Marrakech: Atlas Major, in convalle fluminis Ait Messane, loco humido umbroso ad pedem rupis supra pagum Arroud, 2.100 m, 19-VII-1923, R. de Litardière s.n. ( $\mathrm{G}$ - holotype).

Habitat and phenology. Wet rocky places and in Eryngion variifolii Quézel 1957 (Taleb \& Fennane 2019), 2040-3000 m; flowering and fruiting at end of June, July and early August.

Specimens examined. MOROCCO. Marrakech: Oukaïmeden area, $\mathrm{N}$ slopes of Tizi'n-Eddi, $2700 \mathrm{~m}, 31^{\circ} 10^{\prime} \mathrm{N}, 7^{\circ} 51^{\prime} \mathrm{W}$, megaforbics. Adam Boratyński \& Angel Romo, 26-VII-2002, Romo 10594-03. Grand Atlas: Vallée de l'Acif-n-Ouelga, rochers porphyriques suitantes, rive gauche $3000 \mathrm{~m}$ env. R. de Litardière, 1 août 1923, G, (ut A. vulgaris s.lat.). Grand Atlas, Reraya: Arround, rive dr. de l'Acif-n-Ait Mesan, au bord du sentier du Sidi Chamarouch, Eyngium variifolium, expos. NW, $2040 \mathrm{~m}$ env. R. de Litardière, 19 juillet 1923, G. In Atlantis Majoris ditione Mesfioua: in scatu-/raginosis mont Aouljdid, solo granitico/ 2700 m/ R. Maire 12-VII-1924/ Iter Maroccanum octavum/ G 00191239. High Atlas, surroundings of Oukaïmeden, 2600$3000 \mathrm{~m}$, siliceous soils, $7^{\circ} 51^{\prime} \mathrm{W}, 21^{\circ} 11^{\prime} \mathrm{N}$, Leg. W. Lippert $\mathrm{n}^{\circ}$ 25575, det. D. Podlech, New York Botanical Garden 02482313, duplum ex herb. W, [ut $A$. atlantica (Emb.) H. Lindb.].

Alchemilla gourzae M. Ibn Tattou in Fennane \& Ibn Tattou in Trav. Inst. Sci., Sér. Bot. 37: 405. 2005.

Type: Morocco. Marrakech: Mount Gourza au dessus d'Amismiz, 2800 m, 29-VI-1925, R. Maire s.n. (sub A. vulgare; MPU - Maire - holotype).

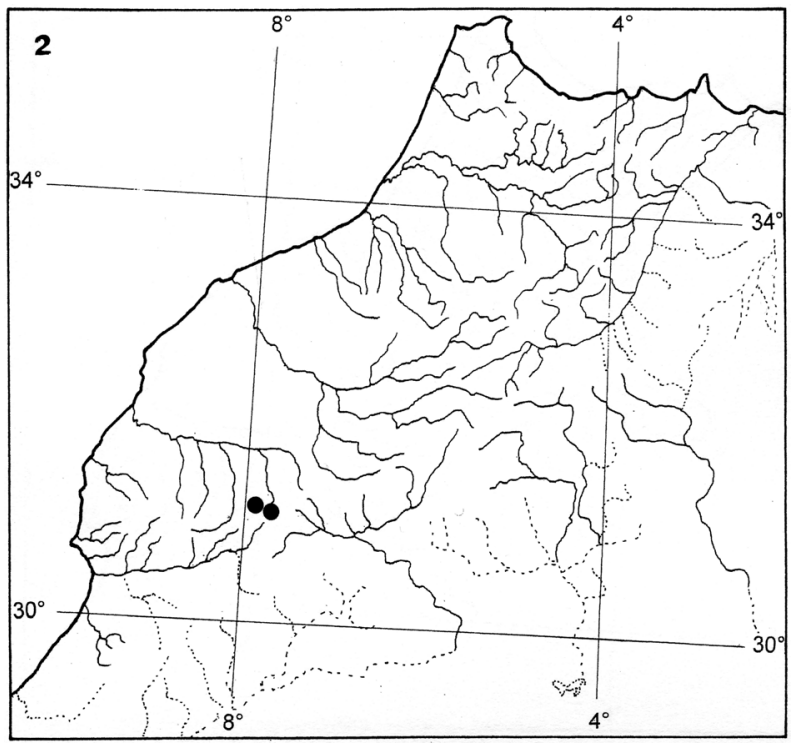

Figure 3. Distribution map of Alchemilla atlantica. 
Distribution. Endemic to the High Atlas Mountains (Fig. 4).

Habitat and phenology. Wet high altitude meadows, 2700-3300 m; flowering and fruiting in July and early August.

Specimens examinated. MOROCCO. Marrakech: In Atlantis Majoris monte Gourza supra oppidum/ Amismiz: in scaturiginosis, $2800 \mathrm{~m} /$ die 29 junii/. Dr. R. Maire, Iter Maroccanum decimum/ 1925. (MPU 006055), (ut Alchemilla vulgaris subsp. lindbergiana). Revised by Werner Rothmaler on 23-II-1935. In Atlantis Majoris montibus supra oppidum/ Amismiz: in scaturiginosis montis/Gourza, 2700-2900 m solo schistaceo/ die 29 junii/. Dr. R. Maire, Iter Maroccanum Decimum/ 1925. (MPU 310699), (ut Alchemilla vulgaris subsp. lindbergiana). Grand Atlas: Mont Gourza, ruisselets, 2800 m/ 29-6-1925/ Dr. R. Maire/ Université d'Alger/ Herbier Afrique du Nord. (MPU 006056), (ut Alchemilla vulgaris subsp. lindbergiana). In Atlantis Majoris ditione/ Mesfioua; in scaturiginosis mont Aouljdid, solo granitico/ 2700 m/ 12-VII-1924./ Dr. R. Maire - Iter Maroccanum octavum/ G 00191239.

Alchemilla litardieri H. Lindb., Itin. Mediterr., Act. Soc. Sci. Fenn. N.s. B, 1: 72-73. 1932.

Type locality description: Morocco. Hoch Atlas, Acif Ouenkrim, Reraia 2700 m, 12-VII-1924, R. Maire s.n. (RAB - holotype).

Distribution. Endemic to the High Atlas Mountains (Fig. 5).

Habitat and phenology. Wet high altitude meadows, 3000-3300 m; flowering and fruiting in July and August.

Specimens examinated. MOROCCO. Marrakech: Grand Atlas, Goundafa: haute vallée de l'Acif Agoundis, pozzine/3.300 m env./ Porphyre/ 2 août/ espèce nouvelle pour l'Afrique. R. de Litardière/ Voyage Botanique au Maroc (Juillet-août 1923). MPU-Maire, (ut Alchemilla pubescens subsp. litardierei, Lindberg pro specie). Grand Atlas, Goundafa: haute vallée de l'Acif Agoundis, pozzine, porphyre $3.300 \mathrm{~m}$ env./ 2 août/ R. de Litardière/ Voyage Botanique au Maroc (Juillet-août 1923), G00191237. Idem in MPU 009612, sheet

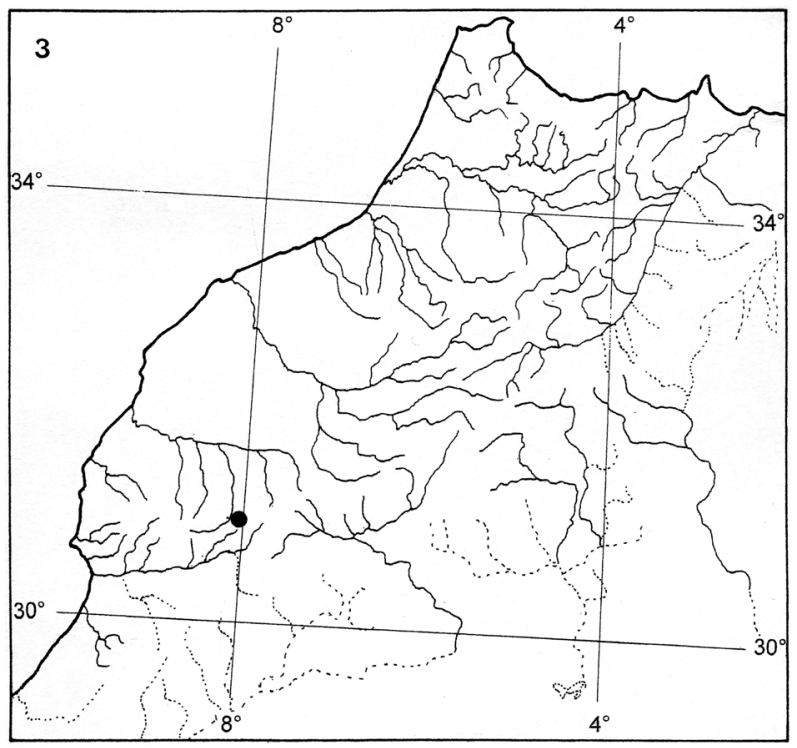

Figure 4. Distribution map of Alchemilla gourzae.

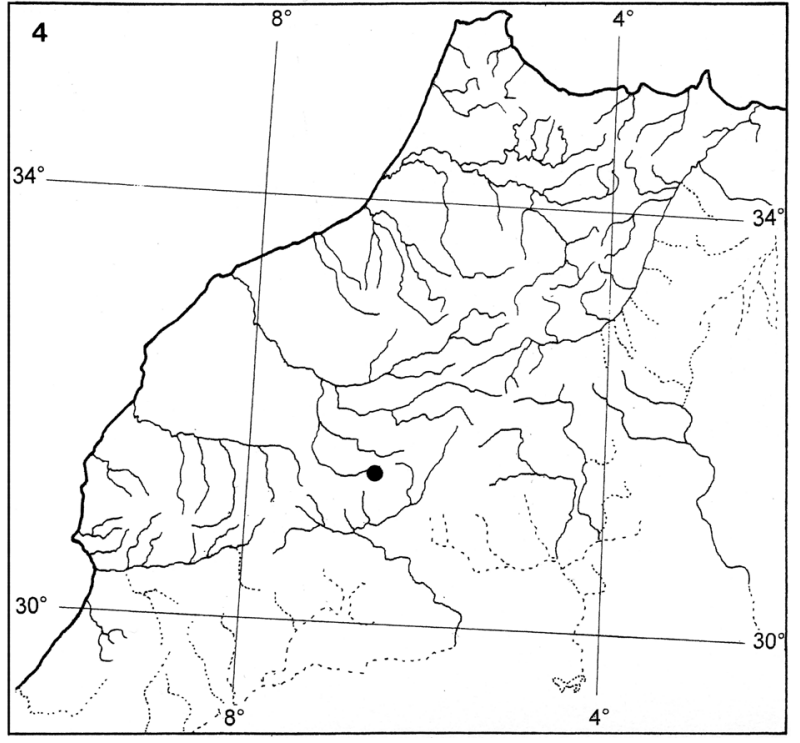

Figure 5. Distribution map of Alchemilla litardieri.

revised by Werner Rothmaler on 23-II-1935 with a label 'Revisio Alchemillarum'.

Alchemilla mairei H. Lindb., Itin. Mediterr. Act. Soc. Sci. Fenn. N.s. B, 1: 72. 1932.

Type locality description: Morocco. Hoch-Atlas, Aouljdid, 2700 m, 12-VII-1924, R. Maire (RAB - holotype).

Distribution. Endemic to the High Atlas Mountains (Fig. 6).

Habitat and phenology. High altitude wetlands and peat bogs, 2250-3350 m; flowering and fruiting at end of June, July and early August.

Specimens examinated. MOROCCO. Marrakech: In Atlantis Majoris Valle Reraya - in pascuis/ turfosis convallis Ouenkrim, solo porphyrico/ supra Isgoum Ouagouns, 3130 m/ 20-VII, Dr. R. Maire - Iter Maroccanum Octavum/ 1924, (ut Alchemilla vulgaris subsp. Mairei). Gran Atlas: pozzines de l'Acif/ Ouenkrim, 2900 m, porphyres/ 24-7-1923/ Leg. R. de Litardière, MPU

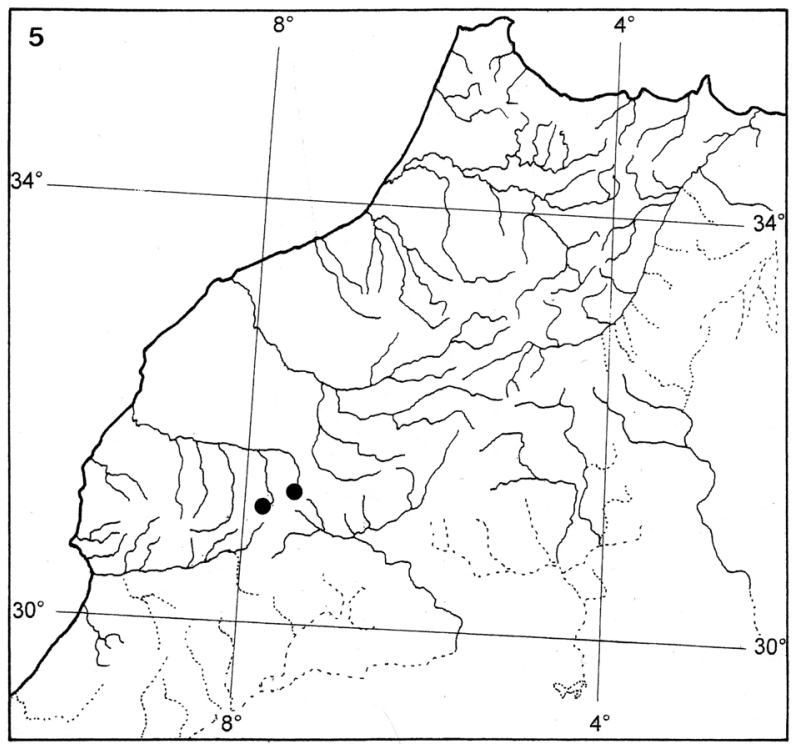

Figure 6. Distribution map of Alchemilla mairei. 
006055/ Université d'Alger/ Herbier de l'Afrique du Nord, (Ut Alchemilla vulgaris L.). In Atlantis Majoris Valle Reraya - in pascuis/ turfosis convallis Immouzer, solo por-/ phyrico, $2900 \mathrm{~m} /$ 22-VII-1924, Dr. R. Maire - Iter Maroccanum Octavum/ 1924, MPU 006054, (ut Alchemilla vulgaris s.lat.)/ (ut subsp. mairei) (Lindberg, pro specie) determined by W. Rothmaler on 23-II1935). Grand Atlas: Reraya, Vallée de l'Acif Ouenkrim, rive g. Eryngietum varifolii expos. ESE, $2550 \mathrm{~m}, 20$ juillet, R. de Litardière (ut A. vulgaris) Plantes du Maroc 1924, G. Grand Atlas: Reraya, Vallée de l'Acif Ouenkrim, rive g., pouzzine en amont de l'Isgoum Ouagouns. Exp. SE. 3130 m, env. 20 juillet 1924, R. de Litardière (ut A. vulgaris) Plantes du Maroc 1924, G. Grand Atlas: Reraya, Vallée de l'Acif Ouenkrim, rive dr. en aval de l'Isgoum Ouagouns, au pied de rochers porphyriques, à l'ubac, 2900 m env., 24 juillet, 1923, R. de Litardière (ut A. vulgaris s.lat.), Voyage botanique au Maroc (Juillet-août, 1923), G. Grand Atlas: Reraya, Vallée de l'Acif/ Ouenkrim, en aval de la bergerie, base rocher/ porph., $2900 \mathrm{~m}$ env., 24 juillet, 1923, R. de Litardière (ut $A$. vulgaris s.lat.), Voyage botanique au Maroc (Juillet-août, 1923), G0019138. Grand Atlas: Reraya, Hte. vallée de l'Acif/ Ouenkrim, rive g., pouzzine en amont de l'Isgoum Ouagouns. Exp. SE. 3130 m, env. 20 juillet 1924, R. de Litardière (ut A. vulgaris) Plantes du Maroc 1924, G.

\section{Discussion}

From the taxonomic point of view, as says Väre (2010), not all the taxa described from Morocco by Harald Lindberg have been evaluated yet. In this framework, three of these taxa are found: Alchemilla atlantica, A. litardieri and $A$. mairei.

According to Dobignard (2016: 158), A. atlantica is an apomictic taxon of a very complex nature, which should include, following his criteria, A. litardierei and A. mairei. Besides, A. litardierei would be a taxon of doubtful status and probably synonymous with $A$. atlantica. This criterion is followed by Fennane (2018).
After analyzing the morphology of the distal lobe apexes of the rosette leaves, the stipules of these same leaves, the upper cauline leaves and stipules, the stem indumentum, the morphology of flowers and the lateral aspects of the nucules, we believe that we are dealing with distinct taxa (see Fig. 7).

Our criterion is reinforced by the specialist in the genus, Werner Rothmaler, who, in his revision of the sheets of the genus Alchemilla from Marruecos in 1935, added in his own handwriting the determinations we uphold here. In the 'Revisio Alchemillarum' labels found in the sheets of Alchemilla kept in MPU, he segregated all the taxa that we here recognize and revaluate. See table 1 and figures 1 and 7 to get a more complete vision of the five taxa of Alchemilla present in Morocco. The development of knowledge of the genus and its taxonomic treatment by the different authors is summarized in Table 2.

\section{Key for the Alchemilla taxa present in Morocco}

Conceptacle and calyx densely hairy all over........ .......................... Alitardieri Conceptacle and calyx glabrous or not very densely hairy $\ldots \ldots \ldots \ldots \ldots \ldots \ldots \ldots \ldots \ldots \ldots, 2$

2(1) Conceptacle and calyx sparsely hairy . .... A. mairei Conceptacle glabrous or sparsely hairy at apex and/or at base............................. 3

3(2) Upper leaf surface glabrous ........ A. boratynskii Upper leaf surface hairy.................. 4

4(3) Hypanthium $>2.5 \mathrm{~mm} \ldots \ldots \ldots \ldots$. A. atlantica Hypanthium $<2.5 \mathrm{~mm}$.............. A. gourzae

Table 1. Comparative table of the species knownfrom Morocco to date.

\begin{tabular}{|c|c|c|c|c|c|}
\hline Characters & $\begin{array}{l}\text { Alchemilla } \\
\text { boratynskii }^{1}\end{array}$ & $\begin{array}{l}\text { Alchemilla } \\
\text { atlantica }^{2}\end{array}$ & $\begin{array}{c}\text { Alchemilla } \\
\text { gourzae }^{3}\end{array}$ & $\begin{array}{l}\text { Alchemilla } \\
\text { litardieri }^{4}\end{array}$ & $\begin{array}{c}\text { Alchemilla } \\
\text { mairei }^{5}\end{array}$ \\
\hline Ventral side of leaves & $\begin{array}{l}\text { glabrous except on } \\
\text { margin and teeth }\end{array}$ & sparsely pilose & sparsely pilose & densely pilose & sparsely pilose \\
\hline Leaf folds on ventral side & sericeous & pilose & pilose & sericeous & sparsely pilose \\
\hline Dorsal side of leaves & $\begin{array}{l}\text { glabrous except on } \\
\text { teeth and margin, } \\
\text { which are hairy }\end{array}$ & sparsely pilose & sparsely pilose & sparsely pilose & sparsely pilose \\
\hline Radical leaf segments & $\begin{array}{c}\text { connate, incisions } \\
1 / 2-1 / 3 \\
\end{array}$ & $\begin{array}{c}\text { connate, incisions } \\
1 / 3-1 / 4\end{array}$ & $\begin{array}{c}\text { connate, incisions } \\
1 / 3\end{array}$ & $\begin{array}{c}\text { connate, incisions } \\
1 / 3-1 / 4\end{array}$ & $\begin{array}{c}\text { connate, incisions } \\
1 / 3\end{array}$ \\
\hline Cauline leaf segments & connate & connate & connate & connate & connate \\
\hline Teeth mm & $1.5-2$ & $1-2$ & $1-1.5$ & $1-1.5$ & 1 \\
\hline Pedicels mm & $3.5-4.5$ & 1 & $1-1.5$ & $1.5-2$ & $1-2$ \\
\hline Hypanthium & 2.5 & $2.5-3$ & $2-2.5$ & 2.5 & 2.25 \\
\hline Epicalyx mm & $0.6-0.8$ & $0.5-0.7$ & $0.6-0.7$ & $0.6-0.7$ & $0.8-0.9$ \\
\hline Sepals mm & $1-1.25$ & $0.8-1(1.5)$ & $1-1.35$ & $0.8-1$ & 1.25 \\
\hline
\end{tabular}

Origin of the material used for compiling the table: ${ }^{1}$ Morocco. Marrakech: Oukaïmeden area, N slopes of Tizi’n-Eddi, $2700 \mathrm{~m}, 31^{\circ} 10^{\prime} \mathrm{N}, 7^{\circ} 51^{\prime} \mathrm{W}$, megaforbics, near the stream. A. Boratyński \& A. Romo, 26-VII-2002, Romo 10594. ${ }^{2}$ Morocco. Marrakech: Oukaïmedene area, N slopes of Tizi'n-Eddi, $2700 \mathrm{~m}, 31^{\circ} 10^{\prime} \mathrm{N}, 7^{\circ} 52^{\prime} \mathrm{W}$, scrubs on sandstone rocks. A. Boratyński \& A. Romo, 26-VII-2002, Romo 10594. ${ }^{3}$ Morocco. Marrakech: In Atlantis Majoris monte Gourza supra oppidum/ Amismiz: in scaturiginosis, 2800 m/ die 29 junii/. Dr. R. Maire, Iter Maroccanum decimum/ 1925, (ut Alchemilla vulgaris L./ subsp. lindbergiana Emb. in MPU-Maire). ${ }^{4}$ Morocco. Marrakech: Giundafa: haute vallée de 1'Acif Agoundis, pozzine/3.300 m env./ Porphyre/ 2 août/ espèce nouvelle pour 1'Afrique. R. de Litardière/ Voyage Botanique au Maroc (Juillet-août 1923). MPUMaire, (ut Alchemilla pubescens Lamk (s.lat.: sensu lato)/ subsp. litardierei, Lindberg pro specie). ${ }^{5}$ Morocco. Marrakech: Gran Atlas: pozzines de l'Acif/ Ouenkrim, 2900 m, porphyre/ 24-VII-1923/ R. de Litardière/ Université d'Alger/ Herbier de l'Afrique du Nord/ Alchemilla vulgaris L. s.lat. (vidit A. mairei Lindb./ det W. Rothmaler 1935/2/23), MPU-Maire. 

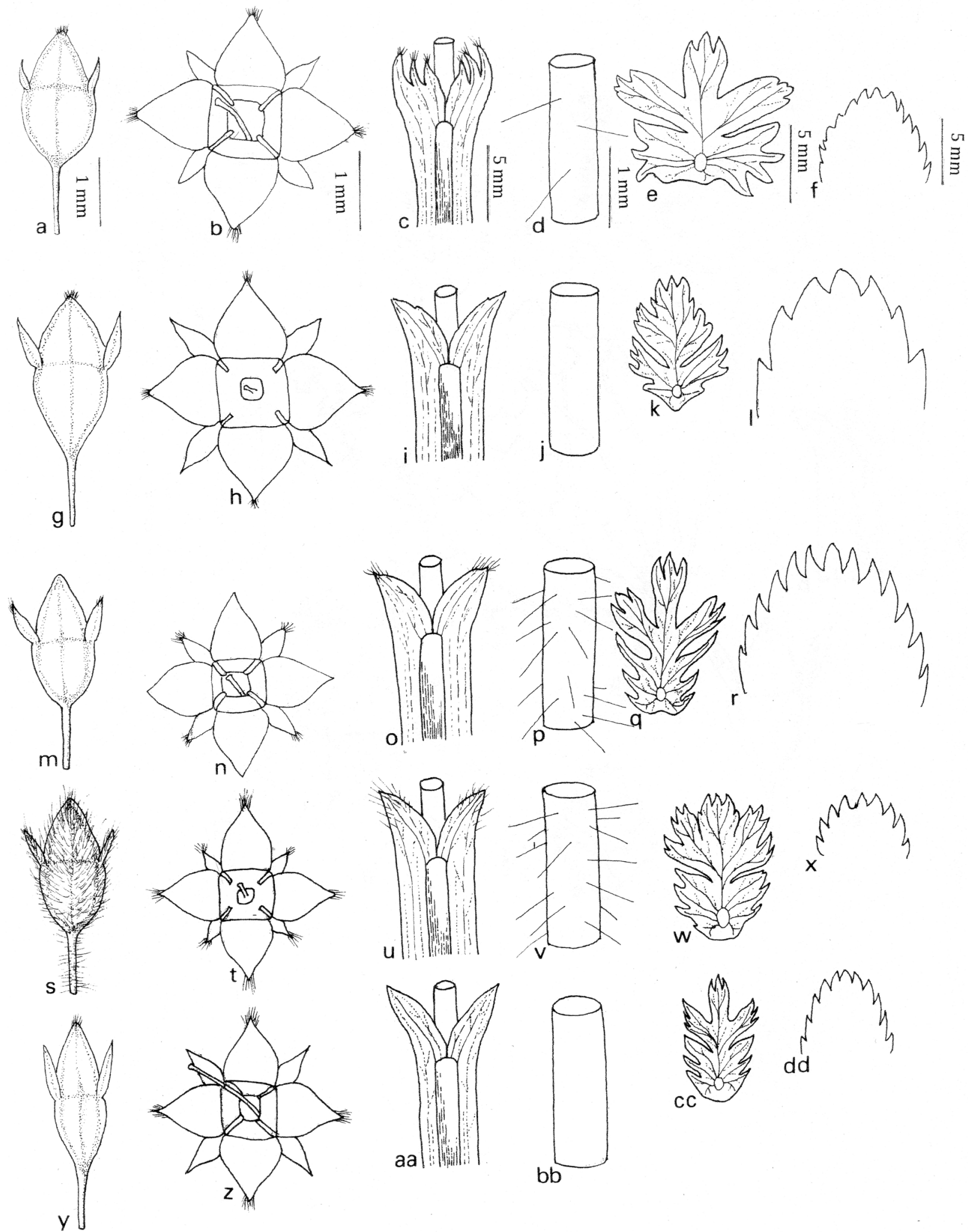

Figure 7. Side view of nucule, flower seen from above, side view of nucule, upper cauline leaf and stipule (laid flat), stem, stipule of the rosette leaf, apex of the distal lobe of a rosette leaf; a-f - Alchemilla atlantica; $\mathrm{g}-1-$ A. boratynskii; $\mathrm{m}-\mathrm{r}-$ A. gourzae; s-x - A. litardieri; $\mathrm{y}-\mathrm{dd}-$ A. mairei. Drawn by A. Romo. 
Table 2. Evolution of the knowledge of the genus Alchemilla in different floras and studies of wild plants from Morocco.

\begin{tabular}{|c|c|c|c|c|c|}
\hline Emberger \& Maire (1934) & $\begin{array}{l}\text { Emberger \& Maire (1941) } \\
\text { and Lindberg (1932) }\end{array}$ & $\begin{array}{c}\text { Fennane \& Ibn } \\
\text { Tattou (1998) }\end{array}$ & $\begin{array}{l}\text { Fennane et al. } \\
\qquad(2005)\end{array}$ & $\begin{array}{c}\text { Dobignard } \\
\& \text { Chatelain (2013) } \\
\text { and Fennane (2018) }\end{array}$ & Present study \\
\hline \multirow[t]{5}{*}{ A. vulgaris s.lat. } & A. vulgaris subsp. atlantica & A. atlantica & A. atlantica & A. atlantica & A. atlantica \\
\hline & & A. hirtipes & & & \\
\hline & \multirow[t]{2}{*}{ A. vulgaris subsp. lindbergiana } & A. lindbergiana & A. lindbergiana & A. gourzae & A. gourzae \\
\hline & & A. litardieri & A. litardieri & & A. litardieri \\
\hline & A. vulgaris subsp. mairei & A. mairei & A. mairei & & A. mairei \\
\hline A. pubescens s.lat. & & & & & A. boratynskii \\
\hline
\end{tabular}

\section{Taxa that should be excluded from the Moroccan Flora}

Alchemilla hirtipes Buser in Bull. Herb. Boiss. Ser. II: 473-474. 1901.

This taxon was noted by Emberger \& Maire (1941) and by Maire (1980: 228) from the High Atlas Mountains, and subsequently listed as doubtful by Fennane \& Ibn Tattou (1998: 155) from the High Atlas Mountains, from Mesfioua, and from the Jbel Aoulijdid. Later, indeed, it was not included by Ibn Tattou (1999) in the Flore Pratique du Maroc. Following this, Fennane \& Ibn-Tattou (2005) considered that its presence in Morocco should be confirmed. Dobignard and Chatelain (2013) consider that it should be included in A. atlantica, but regarding this taxon in the sense of $A$. hirtipes auct Maroc, non Buser.

Alchemilla hirtipes is endemic to the Borniese region of Italy (Pignatti 1982) and its supposed presence in the Atlas Mountains is clearly erroneous. It is a taxon of doubtful presence in Morocco and one that consequently should be excluded from her Flora.

\section{Conservation status}

In Morocco, the taxa of Alchemilla are at the southern periphery of the genus' range. These taxa are important to the conservation of biological diversity (Channell \& Molino 2000) for their location and because they represent the ability of a typical eurosiberian genus to colonize extreme southern habitats in peripherical high mountains under past climatically favorable conditions. All the taxa described are endemic to the High Atlas range of Morocco, from where they are known, without exception, from less than five localities for each one of the taxa. They are very sensitive plants to climatic change and pastoral pressure.

It is necessary to explore and do more fieldwork to locate new populations, as well as monitor the known populations in the High Atlas Mountains.

Little information can be found regarding the rare nature of these species in the literature. Alaoui et al. (2009a, 2009b) consider A. atlantica to be a very rare plant and Dobignard (2016) mentions the scarcity of the accessible populations of Alchemilla in Morocco.

No references have been found on the dangers involving these species. However, A. gourzae has been regarded as Critically Endangered by Fennane (2018) and the other taxa should be considered as vulnerable (IUCN 2012).
If it is assumed that winter snow contributes to better conservation conditions for the high mountain wet meadows and, consequently, for the apomictic plants found therein (Hörandl 2010), the future for species of Alchemilla is not very promising.

\section{References}

Alaoui Haroni, S., Alifriqui, M. \& Ouhammou, A. 2009a. La diversité floristique des pelouses humides d'altitude: cas de quelques sites du Haut Atlas Marocain. Acta Botanica Malacitana 34: 91-106. https:// doi.org/10.24310/abm.v34i0.3147

Alaoui Haroni, S., Alifriqui, M. \& Simonneaux, V. 2009b. Recent dynamics of the wet pastures at Oukaïmeden plateau (High Atlas mountains, Morocco). Biodiversity and Conservation 18: 167-189. https://doi.org/10.1007/s10531-008-9465-6

Briggs, D. \& Walters, S. M. 2000. Plant Variation and Evolution. Cambridge University Press, Cambridge.

Buser, R. 1901. Les Alchemilles Bormiaises. Bulletin de l'Herbier Boissier. Série 2: 461-477.

Channell, R. \& Molino, M. V. 2000. Dynamic Biogeography and Conservation of endangered species. Nature 403: 84-86. https://doi. org/10.1038/47487

Dobignard, A. 2016. Iter maroccanum 2014. Compte rendu de la 49ème session extra. de la Soc. bot. du Centre-Ouest dans le Grand Atlas marocain (7-15 juin 2014). Evaxiana 2: 107-252.

Dobignard, A. \& Chatelain, C. 2013. Index synonymique de la Flore de l'Afrique du Nord. Volume 5. Editions des Conservatoire et Jardin Botanique, Ville de Genève.

Emberger, L. \& Maire, R. 1934. Catalogue des plantes du Maroc. Tome troisième. 559-914 + LVII pp. Imprimerie Minerva, Alger.

Emberger, L. \& Maire, R. 1941. Catalogue des plantes du Maroc. Tome quatrième. Supplément aux volumes I, II, III. 915-1181 + LXXV pp. Imprimerie Minerva, Alger.

Fennane, M. 2018. Eléments pour un Livre rouge de la flore vasculaire du Maroc. Fasc. 9. Polygalaceae - Zygophyllaceae (version 1, Septembre 2018). Edit. Tela-Botanica.

Fennane, M. \& Ibn Tattou, M. 1998. Catalogue des plantes vasculaires rares, menacées et endémiques du Maroc. Bocconea 8: 5-243.

Fennane, M. \& Ibn Tattou, M. 2005. Flore vasculaire du Maroc. Inventaire et chorologie, volume 1. Travaux de l'Institut Scientifique, série botanique 37: 1-484.

Fröhner, S. E. 1995. Alchemilla. In: Scholz, H., Conert, H. J., Jäger, E. J., Kadereit, J. W., Schultze-Motel, W., Wagenitz, G., Weber, H. E. (Eds), Hegi: Illustrierte Flora von Mitteleuropa, vol. 4 Teil 2B, pp. 13-242. Verlag Paul Parey, Berlin.

Fröhner, S. E. 1998. Alchemilla. In: Muñoz-Garmendia, F. \& Navarro, C. (Eds). Flora Iberica 6, pp. 195-357. Consejo Superior de Investigaciones Científicas, Madrid.

Gehrke, B., Bräuchler, C., Romoleroux, K., Lundberg, M., Heubl, G. \& Eriksson, T. 2008. Molecular phylogenetics of Alchemilla, 
Aphanes and Lachemilla (Rosaceae) inferred from plastid and nuclear intron and spacer DNA sequences, with comments on generic classification. Molecular Phylogenetics and Evolution 47: 1030-1044. https://doi.org/10.1016/j.ympev.2008.03.004

Hörandl, E. 2010. Evolution and biogeography of alpine apomictic plants. Taxon 60: 390-402. https://doi.org/10.1002/tax.602009

Ibn Tattou, M. 1999. Alchemilla. In: Fennane, M., Ibn Tattou, M., Mathez, J., Ouyahya, A. \& El Oualidi, J. (Eds) Flore Pratique du Maroc. Vol. 1. Travaux de l'Institut Scientifique, série botanique 36: 493-494.

IUCN. 2012. Guidelines for Application of IUCN Red List Criteria at Regional and National Levels. Version 4.0. Gland, Switzerland and Cambridge.

Kurtto, A. Fröhner, S. E. \& Lampinen, R. 2007. Atlas Florae Europaeae. Distribution of Vascular Plants in Europe. 14. Rosaceae (Alchemilla and Aphanes). The Committee for Mapping the Flora of Europe \& Societas Biologica Fennica Vanamo. Helsinki.

Lindbeg, H. 1932. Itinera Mediterranea. Ein beitrage zur Kenntnis der Westmediterranean Flora und grubd eines materials vor Gefässpflanzen gesaammelt in Tunisien und Sizilien in Jahre 1924, und in Spanien und Morokko in Jahre 1926. Acta Societatis Scientiarum Fennica. Nova serie B 1, no 2: 1-178.

Maire, R. 1980. Flore de l'Afrique du Nord. Vol. 15. Éditions Lechevalier, Paris.

Pignatti, S. 1982. Flora d'Italia. Vol. I. Edagricole, Bologna.

Pihu, S., Hõimra, J., Köster, E. \& Pärtel, M. 2009. Environmentally Dependent Morphological Variability in Seven Apomictic Microspecies from Alchemilla L. (Rosaceae). Folia Geobotanica 44(2): 159-176. https://doi.org/10.1007/s12224-009-9034-0
Plocek, A. 1982. Revisited nomenclature of infrageneric groups of Alchemilla in Eurasia. Preslia 54: 45-53.

Quézel, P. 1957. Peuplements végétaux des hautes montagnes de 1'Afrique du Nord. Essai de synthèse biogéographique et phytosociologique. Éditions Lechevalier, Paris.

Romo, A. M. 1991. Dos nuevas especies de Alchemilla, de los Pirineos y montañas Cantábricas respectivamente. Estudios del Museo de Ciencias Naturales de Álava 6: 43-48.

Romo, A. M. 2009. Contribution to the knowledge of the Moroccan mountain vegetation. Collectanea Botanica (Barcelona) 28: 111124. https://doi.org/10.3989/collectbot.2008.v28.011

Romo, A. M. \& Boratyński, A. 2007. Notes and contributions to the vascular flora of Oukaïmeden. Candollea 62: 69-89.

Rothmaler, W. 1934. Systematische Vorarbeiten zu einer Monographie der Gattung Alchemilla (L) Scop. I. Feddes Repertorium 33, $342-350$.

Rothmaler, W. 1935. Systematische Vorarbeiten zu einer Monographie der Gattung Alchemilla (L.) Scop. II. Feddes Repertorium 37-39: 409-419.

Rothmaler, W. 1936. Systematische Vorarbeiten zu einer Monographie der Gattung Alchemilla (L.) Scop. IV. Die Gruppen der Untergattung Eualchemilla (Focke) Buser. Feddes Repertorium 40, 208-212.

Taleb, M. S. \& Fennane, M. 2019. Vascular plant Communities of Morocco. Phytosociology, Ecology and Geography. Springer Nature Switzerland AG, Cham.

Väre, H. 2010. Harald Lindberg - a Finish botanist. Memoranda Societas Fauna et Flora Fennica 86: 1-27. 